$\overline{\text { 原 著 }}$

\title{
パーソナルコンピュータを用いた失語症者用 言語訓練装置の開発
}

桐谷 滋1) 今川 博 ${ }^{1)}$ 渡辺 陽子 ${ }^{2)}$

要 約 : パーソナルコンピュータを用いた, 失語症者用言語訓練装置を試作したので, 報告 する. 今回の試作では, 語彙訓練を目的として, 学習用の基本的名詞 344 単語と動詞 82 単語の セットを選定し, これらの絵カードと音声のデータをパーソナルコンピュータに入力し, 電子 化辞書として用意した。試作した訓練プログラムの内容は, 名詞学習用に(1)喚語・書字訓練, (2)視聴覚認知訓練, (3)聴覚把持訓練, 動詞学習用に(1)喚語・書字訓練, (2)視覚認知訓練, (3)助 詞訓練である. 訓練プログラムの操作は, 計算機から出力された音声を聴取し, モニ夕画面上 に取り付けたタッチパネルを使用して, 表示された絵カード, 文字, 図形をポインティングす る方式を採用した。意識障害, 肢節運動の失行, 視覚障害のない失語症患者 15 名に試用したと ころ, 約半数では自習可能であることが確認され, 言語療法士の負担を軽減するという点でも 有用であると思われる。

索引用語 : 失語症, 語彙訓練, パーソナルコンピュータ

\section{Word Training System for Aphasic Patients}

Shigeru Kiritani ${ }^{1)}$, Hiroshi Imagawa ${ }^{1)}$, Yoko Watanabe ${ }^{2)}$,

Abstract : A personal computer-based word training system for language therapy of aphasic patients was constructed at the institute listed below. The system aims to assist self -training by aphasic patients in language therapy. In the present paper, characteristics of the training programs developed for this system will be described. The word training procedures currently used in the clinical field in Japan were surveyed with reference to several textbooks on language therapy, and a set of procedures which were appropriate for computerized programs was implemented, with digitized data for a basic set of 344 nouns and 82 verbs stored on computer.

The training system is essentially based on pointing response to picture cards displayed on the screen of the personal computer. The speech sound corresponding to one of the displayed cards is presented through a D/A converter, and the patient makes a response by pointing to a displayed picture card. All responses and program operations are performed

${ }^{1}$ 東京大学医学部音声言語医学研究施設： ₹ 113 東京都文京区本郷 7-3-1

${ }^{2)}$ 東京専売病院： $\mathbf{T} 108$ 東京都港区三田 $1-4-3$

${ }^{1}$ Research Institute of Logopedics and Phoniatrics, Faculty of Medicine, University of Tokyo : 7-3-1 Hongo, Bunkyo-ku, Tokyo113

${ }^{2)}$ Tokyo Sembai Hospital : 1-4-8 Mita, Minato-ku, Tokyo 108

原稿受理：1994 年 5 月 10 日 
through a touch panel attached to the surface of the monitor.

The training programs are as follows :

1) Basic naming/writing of noun words

2) Auditory comprehension training

a) Pointing

b) Yes-no answering

3) Auditory memory-span training

a) Word sequence training

b) Noun phrase training

This system is being used experimentally for 15 aphasic patients without disturbance of consciousness, limb kinetic apraxia and disturbance of eyesight at the hospital listed above, and it seems that the system is useful for aphasic patients, especially for Wernicke's aphasia. Using this system, patients are able to do self-training as many times as they want and speech therapists are thus able to save time and offer therapy sessions to other patients.

Key words : personal computer, word-training program, aphasic patients, self-training

\section{I .はじめに}

現在, 失語症患者の言語訓練は, 患者の状態その他 の状況に応じた，個々の言語療法士の適応的な工夫に 負っている.そのための言語療法士の負担は大きい. また，患者の側からみれば，言語療法士の手不足によ り十分な量の言語訓練を受けられないという問題が生 じていると考えられる．多様な訓練様式のすべてを計 算機を用いて自動化することは不可能であろう。しか しながら，訓練のある程度の部分を自動化され，失語 症患者の自習補助装置を実現することができれば，そ の実際的意義は大きいと考えられる11.

このような言語訓練では，基本的にある程度まとま つた量の絵カードと音声を用いることが必要である. 近年, パーソナルコンピュータの性能の向上により, 比較的小型の装置でこのようなデータが取扱い可能で あり，実際的な訓練装置の実現可能となっている。こ のような装置も 1,2 試作されている ${ }^{2 \sim 4)}$. しかし, こ れらの装置は仮名の書字訓練など比較的機能が限定さ れており，体系的な語彙学習訓練を扱ったものはみあ たらない。一方，市販されている装置もいくつかある が5), 失語症者用訓練用には工夫すべき点が残されて いると考えられる。

本研究では, 主として語彙訓練を中心として, まず 学習用の基本的な名詞および動詞のセットを選定し, それらの絵カードおよび音声のデータをパーソナルコ ンピュータに入力して，いわゆる電子化辞書として用 意した。また，このデータを用い，従来の言語訓練の 指導書などに記載されている訓練方式の中でプログラ
ム化可能かつ有効と考えられるものをいくつか選択し て, 計算機プログラムを作成した，以下ではここで試 作した訓練システムの内容を報告する。

\section{II. 装置の概要}

学習装置の構成を図 1 に示す。単語学習のプログラ ムの基本は, 計算機のモ二夕上に表示された絵カード のポインティングである. 教材となる絵カードや音声 のデータはデジタル化してハードディスクにあらかじ め記憶しておく、計算機は, まず画面に数枚の絵カー ドを表示する. 次に, そのうちの一つの単語の音声を $\mathrm{D} / \mathrm{A}$ 変換器を通して出力する. 学習者はその音声に該 当する絵をポインティングする. 学習者の反応はモ二 夕画面上に装置したタッチパネルにより計算機に入力 される. 計算機は学習者の解答の正誤を判定し, 絵力 ード上に○印や×印を表示して学習者にフィードバッ クする。このようなプログラムを原型とし，いくつか の目的に応じたプログラムを作成した。

計算機は PC-9801 を用いた. 絵カードのデータはイ メージスキャナにより計算機入力し, 音声は 12 bit, 10 $\mathrm{kHz}$ サンプリングして計算機入力した. タッチパネル は $40 \times 25$ の分解能を持つ。

\section{III. 名詞学習プログラム}

\section{1. 学習用単語データ}

学習用名詞として, 基本的名詞 344 単語を選択した。 単語選定にあたっては, これまでに市販されている失 語症者言語訓練用の絵カードセット ${ }^{6,7}$ および幼児教 育用のいくつかの資料を参考にし，これらの資料中の 


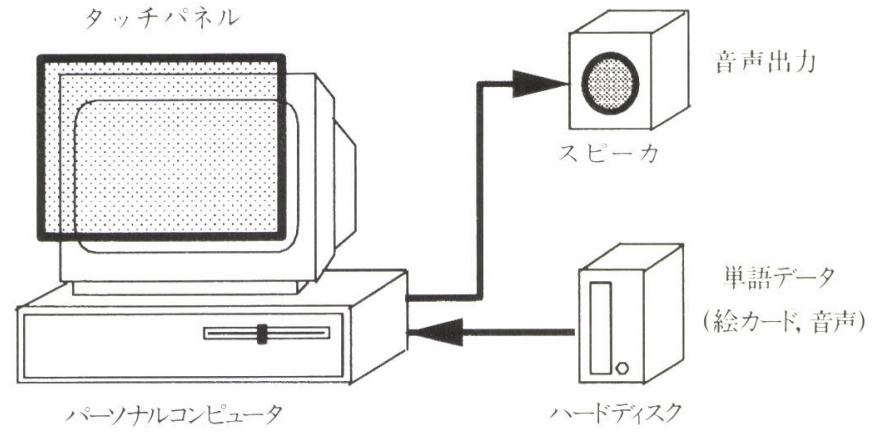

図 1 パーソナルコンピュータを用いた言語訓練装置の構成

単語のほぼす心゙てを網羅した。これらの単語の絵カー ドを新たに描画，制作した。この絵カードをイメージ スキャナを用いて計算機に入力し，ハードディスクに 記憶した.絵カードのデータは 1 枚あたり $208 \times 120$ 画 素で，16色すなわち4 bitの力ラー情報を持つ。絵力 ード 1 枚あたりのデー夕量は 12.5 kbyte である。一 方, 絵カードに対応する音声デー夕は $10 \mathrm{kHz}$ サンプ リング, 12 bit 精度で記憶した。名詞単語音声の平均時 間長は 0.7 秒であり，1 単語あたりのデー夕量は 14 kbyteである。全名詞学習データセットのデー夕量は 17 Mbyte で, 量的には最近のパーソナルコンピュータ 用のハードディスクに容易に収容できる。なお，絵力 ード，音声のデータとともに各単語の文字データ（漢 字，ひらがな，力タカナ）も用意し，単語文字の表字 もできるようにした。

\section{2.プログラムの概要}

主として笹沼らの「失語症の言語治療」7を参考に計 算機プログラム化可能なものとして以下のものを選定 した。

1）喚語書字訓練基本プログラム：画面に表示した 絵力ードの単語音声の視聴や, 文字の表示, 確認が可 能. 基本的な電子辞書と考えることができる.

2 ) 視聴覚認知訓練プログラム：聴覚的認知あるい は文字の視覚的認知能力を高めるためのプログラム。

(a) ポインティングプログラム; 単語音声を呈示 し，対応する絵カードをポインティングさせる。

(b) 正誤判断プログラム；絵カードと組み合わされ て呈示される音声や文字の正誤判断を行わせる。

(c) 文中単語認知プログラム；問題文と質問文を音 声で呈示し，文中の単語に対応する文字カードをポイ ンティングさせる。

3 ) 恥覚的把持訓練プログラム：

(a) 単語系列把持訓練プログラム；いくつかの単語 系列の音声を呈示し, 絵カードをポインティングさせ

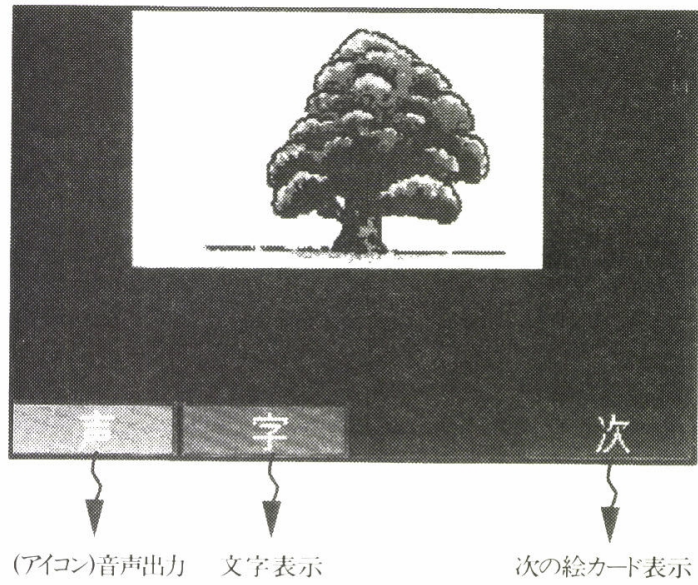

図 2 喚語・書字訓練基本プログラムの表示画面

る.

（b）名詞句把持プログラム；「形容詞十名詞」など の名詞句音声を呈示し，対応する絵カードをポインテ イングさせる。

上記のプログラムにおいて学習者がポインティング して解答するための計算機モ二夕上の表示としては, (1)絵カード, (2)文字, (3)絵カードと文字の表示, の3 つの形式が用意されている。訓練の目的に応じてその うちの1つを選択して使用する。な抒，次節では簡単 のため, 原則として「音声を呈示し, 絵カードをポイ ンティングする」モードについて説明する。また，学 習者のレベルや訓練目的に対応して以下のものを用意 した。(1)344 単語中，実際にその日の訓練に用いる単 語のサブセットの指定，(2)ポインティングのために表 示する解答用力ード（選択肢）の数の指定，(3)練習回 数の指定, (4)夕ッチパネルの反応時間の指定, (5)解答 用力ードの)表示形式(絵力ードのみ, 絵力ード+文字, 文字のみ）の指定などが可能である。また，1回 1 回 
の訓練プログラム終了時に学習者ごとのフロッピイ ディスクに成績を記録, 保管する。

\section{3. 喚語書字訓練基本プログラム}

このプログラムでは 1 枚の絵カードを計算機の画面 に表示する、学習者には, まず絵力ードの単語の喚語 あるいは書字を試みることを求め, 必要に応じて計算 機に当該単語の音声や文字を出力させて確認するよう に指示する。この操作は夕ッチパネルよりアイコンを ポインティングすることによって行う.アイコンの
「声」をポインティングすると声が出力され,「字」を ポインティングすると画面に数秒間単語の文字が表示 される.これらの操作は繰り返し, 何回でも行うこと ができる.アイコン「次」をポインティングすると表 示は別の絵カードに変わり, 次の単語学習に移る。こ のプログラムに拈ける表示画面の例を図 2 に示す.

4. 視聴覚認知訓練プログラム

1) ポインティング

図 3 にポインティングプログラムの流れを示す。こ

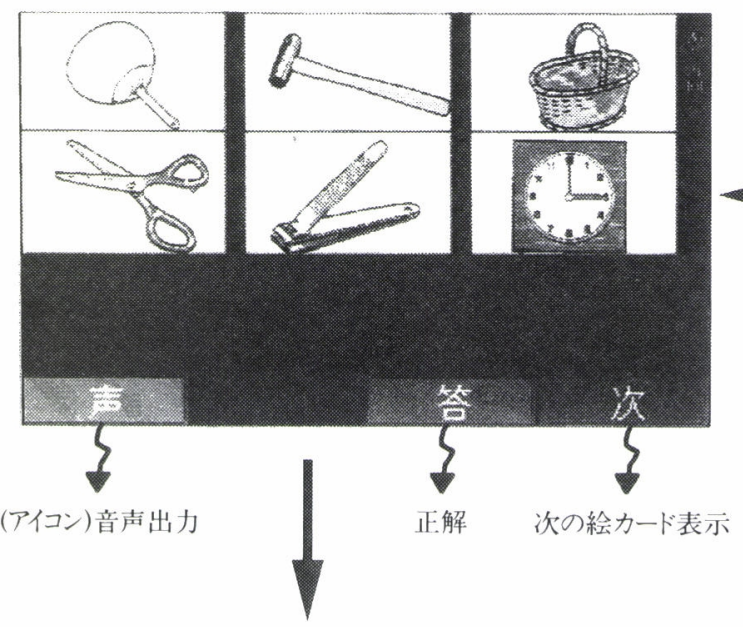

(どれか 1 枚の絵カードの音声出力)

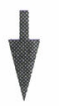

(ポインティング)
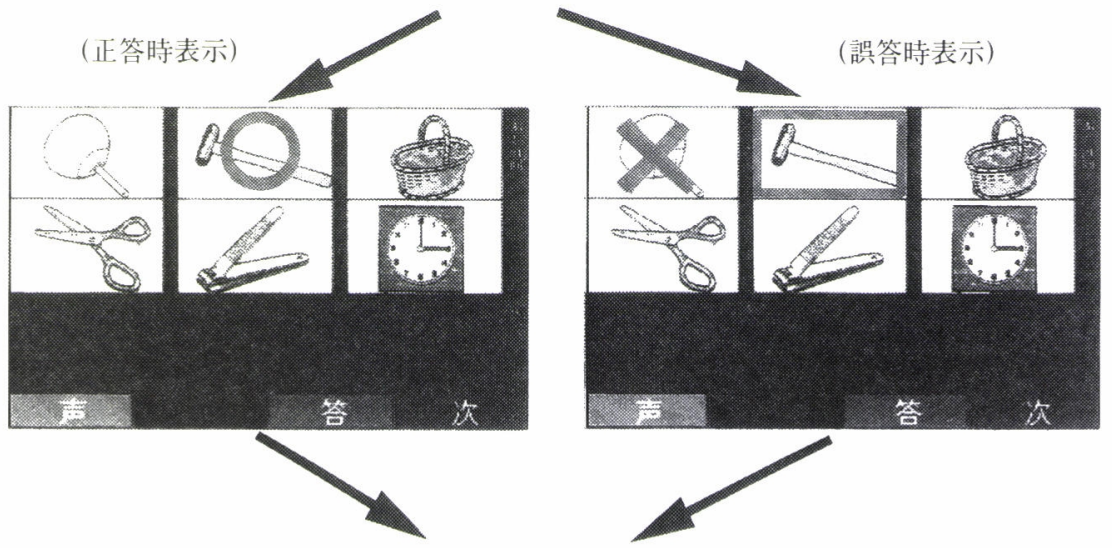

(絵カード交換)

図 3 名詞・ポインティングプログラムの流れ 
のプログラムでは，画面にあらかじめ選択，指定した 枚数 ( 2 枚〜 6 枚) の絵カードが表示される. 次いで, その中の1枚の絵の単語音声が呈示される。学習者は その音声に対応する絵カードをポインティングする. 学習者が答える前に「声」アイコンをポインティング すれば，何度でも単語音声を聞くことができる。学習 者の絵力ードポインティングに対し, 計算機はその正 誤を判定して, 正答時には絵カード上に○印を表示す る。一方，誤答時にはポインティングした絵カード上 にメ印を表示する。「答」アイコンをポインティングす ると, 正しい絵カードが $\square$ 枠で井まれると同時に再度 単語音声が出力され，正答を知ることができる。「次」 アイコンをポインティングすると, 表示されている絵 カードの中で, 正答とされた絵カードのみを別の絵力 ードに置き換え, 次の試行に進む. 表示されている絵 カードすべてを置き換えることもブログラム的には容 易であるが, 従来の一般に行われている方法に従って, ここでは絵カード 1 枚のみを置き換えた。

2) 正䛊判断

画面に 1 枚の絵カードが表示される(図 4). その後,

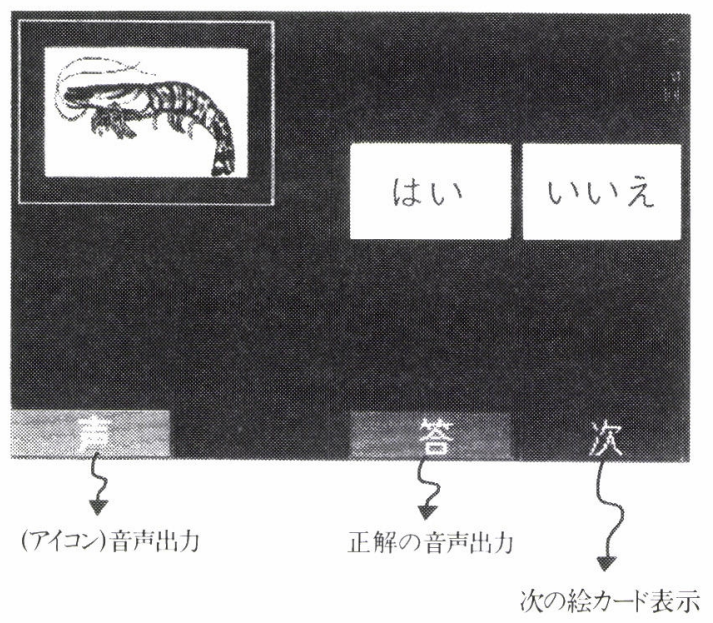

図 4 名詞・正呮判断プログラムの表示画面
単語音声がスピーカから出力される。この単語音声は 絵カードに該当していることもあり, 該当していない こともある。学習者はその音声が絵カードに該当する か否かを判断し，「はい」「いいえ」のいずれかのアイ コンをポインティングする。計算機はその答えの正否 を判定して○印かメ印を表示する。このプログラムで も「声」アイコンを用いて学習者は何度でも出題音声 を聞き直すことができる。また，「答」アイコンで，表 示されている絵カードの正しい音声を聞くことができ る。「次」アイコンをポインティングすると, 次の単語 の学習に進む.

\section{3 ) 文中単語認知}

$2 \sim 5$ 文節からなる短文を呈示し, 文中の単語の認 知の訓練をする。この訓練で用いた文型は『\{いつ\}\{ど こで\}\{誰が\}\{何を\}\{どのくらい\}\{どうした\}』であ る。表 1 に，ここで用いた単語を示す。「何を」「どう した」の文節を必須要素として，他の文節は訓練段階 に応じてあらかじめ指定した文の長さ(文節数 2 ～5 ) に応じて適宜組み合わせる。文中の文節数を 3 と指定 した場合には，『いつ，何を，どうした』『どこで，何 を，どうした』『誰が，何を，どうした』『何を，どの くらい, どうした』の 4 種の形を取り得るが, 出題文 はこれらすべての文の中からランダムに選んで呈示す る.表 1 の単語の組合せにより全部で 13,284 通りの文 を呈示できる。訓練は呈示された文中の各文節につい て質問を行う。たとえば,「デパートでみかんを買った」 の文音声をスピーカから呈示し, 学習者に聞き取らせ る.この後, 学習者が「問」アイコンをポインティン グすると，文中の一つの文節に関する質問音声（たと えば，「何を買いましたか？」)が呈示される。ついで， 画面に 4 個の選択肢(ここでは，「パン」「みかん」「お 握り」「ケーキ」など）の文字カードを表示し, 答えを ポインティングさせる、計算機はその正詋により○印 またはメ印を表示する。また，「答」アイコンをポイン ティングしたときは，正答カードを $\square$ 枠で井んで示す とともに問題文の音声と文字を呈示する。同様に，「ど

表 1 文中単語認知訓練使用単語

\begin{tabular}{|l|l|l|l|l|l|}
\hline いつ & どこで & 誰が & 何を & どのぐらい & どうした \\
\hline おととし & デパート & お母さん & みかん & 少し & 買った \\
先週 & 市場 & お兄さん & パン & 3 個 & 食べた \\
きのう & 京都 & 田中さん & 最中 & 4 個 & 捨てた \\
今朝 & アメリカ & 看護婦さん & お握り & 7 個 & 鿓った \\
& & & ケーキ & & 送った \\
& & & クんご & & 並べた \\
\hline
\end{tabular}


こで買いましたか」「みかんをどうしましたか」を順次 呈示する。「次」アイコンをポインティングすると次の 試行に進む。

\section{5 . 恥覚的把持訓練 \\ 1) 単語系列把持}

図 5 にプログラムの流れを示す. 2 枚〜 6 枚の絵力 ードが表示された後, このうちの $2 \sim 4$ 枚の単語音声 を連続して出力される。学習者はその音声を聞き取り,

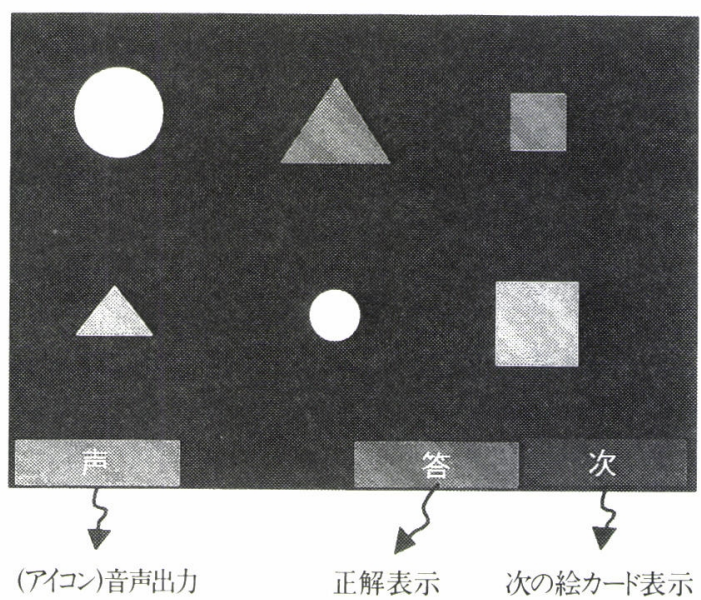

図 5 名詞句・把持訓練プログラムの表示画面

表 2 名詞句による聴覚的把持訓 練使用単語

\begin{tabular}{|c|l|c|}
\hline $\begin{array}{c}\text { 形容詞 1 } \\
\text { [サイズ }]\end{array}$ & $\begin{array}{l}\text { 形容詞 } 2 \\
\text { [色] }\end{array}$ & $\begin{array}{c}\text { 名詞 } \\
\text { [形] }\end{array}$ \\
\hline 大きな & 赤 (い) & 丸 \\
小さな & 白 (い) & 二角 \\
& 青 (い) & 四角 \\
& 黄色 (い) & \\
& 緑 (の) & \\
\hline
\end{tabular}

その順番も記憶する. 音声出力が終わったら, 学習者 はその順番どおりに音声に対応する絵カードをポイン ティングする。計算機は 1 枚の絵カードがポインティ ングされるたびにその正誤を判定し，○印またはメ印 を絵カード上に表示する、誤答であればポインティン グ入力受け付けを停止する. [声]アイコンをポインテ イングすると, 再度音声が出力され, 絵カードのポイ ンティングをやり直すことができる.「答」アイコンを ポインティングすると, 計算機は音声出力時の順番に 従い, 絵カード上に $\square$ 枠を表示するとともに確認のた めの音声を呈示する。「次」アイコンのポインティング で次の絵カードの組の訓練に進む.

\section{2 ) 名詞句把持}

「形容詞十名詞」の語連鎖の聴覚的理解・把持の訓 練を目的とする。ここで用いた語連鎖は表 2 に示す形 容詞 1 (サイズ), 形容詞 2 (色), 名詞 (形) の組合 せで構成される名詞句である，画面にサイズ，色，形 の異なる数個の図形を表示する.たとえば,「大きい丸」 のような 1 個の図形を表現する名詞句音声を呈示し学 習者に対応する図形をポインティングさせる（図５）。 計算機は答の正誤により図形上に○印またはメ印を表 示する.ここでも「声」アイコンで何度も問題音声を 聞くことができ，「答」アイコンで正しい図形上に $\square$ 枠 が表示されるとともに再度音声が出力される。「次」ア イコンをポインティングすると, 別の図形の組に置き 換わり，次の試行に進む。

選択対象として用いる図形の集合としては表 3 に示 したものを用意してあり，訓練の段階に応じて用いる 集合を指定することができ，異なる長さの語連鎖を選 んで使用できる.表中の 6,7 はモ二夕画面に表示さ れた複数の図形から 2 つ図形をポインティングする 問題である。また，画面に表示される選択肢の数も学 習者の能力に応じて設定する．表示される図形の組合 せは呈示された音声の形容詞と名詞の両方とも理解で きないと正答できないようなものとした。

表 3 名詞句による聴覚的把持訓練の訓練段階

\begin{tabular}{|c|c|c|c|}
\hline 段階 & 内 容 & 選択肢 & 例 \\
\hline 1 & 形の選択 & 2,3 & 丸 \\
\hline 2 & 色の選択 & $2,3,4,5$ & 青 \\
\hline 3 & サイズと形の選択 & 4,6 & 大きな丸 \\
\hline 4 & 色と形の選択 & $4,6,8$ & 黄色い丸 \\
\hline 5 & サイズと色と形の選択 & 8 & 小さな白い丸 \\
\hline 6 & 色と形の選択（２択） & $4,6,8$ & 黄色い丸と赤い三角 \\
\hline 7 & サイズと色と形の選択（2 択） & & 大きな青い四角と小さな白い三角 \\
\hline
\end{tabular}




\section{IV、動詞訓練プログラム}

\section{1. 動詞学習用データ}

学習用動詞として, 絵カード作成可能な基本的動詞 82 単語を選択した。各動詞に主語または目的語などの 名詞および助詞を組合わせて単文を設定し，その文を 表現する絵カードを作成した。名詞と動詞の組合せに 用いる助詞は以下の 8 種類である。(1)主語述語の表現 「が」，(2)場所で行われる動作「で」，(3)道具による動作 「で」, (4)到達点「に」, (5)通り道「を」, (6)働きかけ「に」, (7)対面の表現「と」，8共同動作の表現「と」.

1 つの動詞と助詞の組合せについて，できる限り 4 つの異なった名詞を用いた単文を用意した。これは, 学習の初期の段階では動詞と助詞が同一で，名詞のみ 異なる絵カードの組を用いた訓練が動詞の意味の把握 に有効であろうと考えたからである。以上のようにし て用意した文は 346 文である。作成した絵カードは黒 白とし, 計算機に 8 階調の濃淡で記憶した。絵カード サイズは名詞の場合と同じ $208 \times 120$ 画素である.動詞 音声データの平均時間調は 2.1 秒で，動詞の全デー夕 セットは約 18 Mbyteであった。

\section{2. プログラムの概要}

1) 喚語・書字訓練基本プログラム

2 ) 視聴覚認知訓練プログラム

a) ポインティングプログラム

b) 正詋判断プログラム

上記の 3 つのプログラムは名詞訓練プログラムの対 応するものと内容はほぼ同一である。

3 ) 助詞訓練プログラム：1枚の絵カードに対し名 詞と動詞の音声を与え，適切な助詞をポインティング させる。

上記のプログラムにおいても，学習者がポインティ ングして解答するための計算機モニタ上の表示カード の形式の指定，実際にその日の訓練に用いる単語の川 ブセットの指定，解答用カード (選択肢) の数の指定， 成績の記録は名詞と同様に行うことができる。

\section{3. 喚語・書字訓練基本プログラム}

このプログラムでは 1 枚の絵カードを計算機の画面 に表示する.また同時に名詞と助詞の文字を表示する。 学習者は表示された絵カードと文字をみて，名詞と助 詞に続く動詞の喚語あるいは書字を試みる。学習者は 計算機の画面のアイコンをポインティングすることに より，動詞の音声や文字を出力させて答を確認するこ とができる。この操作は名詞訓練の喚語・書字訓練基 本プログラムと同一である。ただし，ここではアイコ ン「文」が追加されており，このアイコンをポインティ
ングすると単文全体（名詞十助詞十動詞）の音声が出 力され，確認のための聴取ができる。

\section{4. 視聴覚認知訓練プログラム}

1) ポインティングプログラム

このプログラムの流れは, 名詞訓練のポインティン グプログラムと同一である。画面に 2 枚〜 6 枚の絵力 一ドが表示され，その中の 1 枚の絵を表す単文の音声 が呈示される。学習者は該当する絵カードをポイン ティングする.図 6 に表示画面の例を示す.この訓練で は表示する絵カードの組合せとして，以下の 3 つの場 合を指定することができる、(1)動詞と助詞が同一で名 詞のみが異なる絵カードを並べて表示する。(2)名詞と 助詞が同一で動詞のみが異なる絵カードを並べて表示 する.(3)絵カードをランダムに選択して並べて表示す る。訓練の段階や学習者のレベルに応じてこのうちか ら選択し使用する。

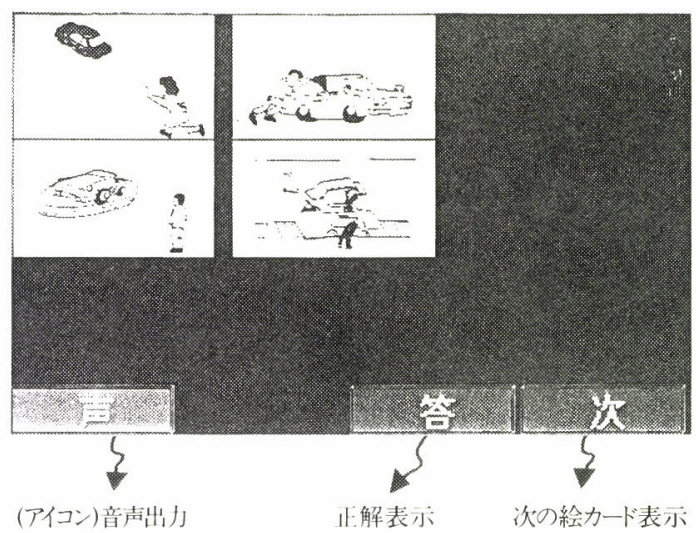

図 6 動詞・ポインティングプログラムの表示画面

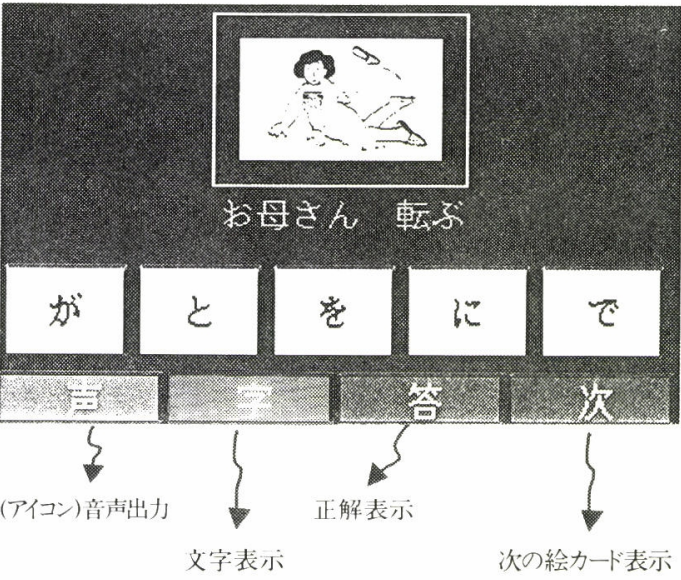

図 7 助詞訓練プログラムの表示画面 
2 ) 正誤判断プログラム

このプログラムの流れも名詞訓練と同一である. 画 面に 1 枚の絵カードが表示され, 単文の音声が出力さ れる．学習者はその音声が絵カードに該当するか否か を判断し,「はい」「いいえ」のいずれかのアイコンを ポインティングする.

\section{5. 助詞訓練プログラム}

画面には 1 枚の絵カードと助詞「が, と, を, に, で」を示す 5 枚の文字カードが表示される(図 7 ).こ の後, 絵カードに対応する単文の助詞を除いた名詞と 動詞の音声が出力される. 学習者はその間に入る助詞 として適切なものの文字カードをポインティングす る. 学習者や解答する前に「声」アイコンをポインティ ングすれば，何度でも問題音声を聞くことができる. また「字」アイコンをポインティングすれば, ヒント として名詞と動詞の文字が画面に表示される. 反応の 正誤に基づき, 学習者がポインティングした助詞の上 に○印や×印を表示する.「答」アイコンでは正しい文 字カード上に口枠が表示される。

\section{V.おわりに}

パーソナルコンピュータを用いた失語症者用言語訓 練装置を試作したのでその内容について報告した。今 回の試作では, まず語彙訓練を目的として, 学習用の 基本的な名詞 344 単語および動詞 82 単語のセットを 選定し, それらの絵カードおよび音声のデータをパー ソナルコンピュータに入力して, 電子化辞書として用 意した.

訓練プログラムとしては, 名詞学習用には喚語・書 字訓練基本プログラム, 視聴覚認知訓練プログラム, 聴覚的把持訓練プログラムを作成し, 動詞学習用には 喚語・書字訓練基本プログラム, 視聴覚認知訓練プロ グラム, 助詞訓練プログラムを作成した。

訓練プログラムの基本は, 計算機から音声を出力し, モニタ画面上に表示された絵カードをポインティング させるものであり，一般の小児用学習プログラムと部 分的には共通している点もあるが, 今回は失語症者の 言語訓練用として以下のような点に工夫を加えた。

反応・操作面については, 患者が反応動作を容易に 行えるように，モニタ画面上に取り付けたタッチパネ ルを使用し, 表示された絵カード, 文字, 図形をポイ ンティングする方式を採用した。 またアイコン操作は すべてのプログラムについてほほ共通の方式で行える ように配慮し, 基本的には, 「声」(問題音声の出力), 「字」(文字表示),「答」(正答の表示),「次」(次の試 行へ移る) の 4 つのアイコンで大部分の操作が行える
ようにした。

プログラム内容については, 失語症者では一般に単 語把持力の訓練が必要とされているので, その目的の ための聴覚的把持訓練プログラムを作成した.さらに， 弧立単語だけでなく, 文中の単語の理解と把持の訓練 を目的として, 文中単語認知訓練プログラムを作成し た。また, 患者に合わせて選択肢の数や試行回数を設 定可能としたが, 特に, それに加えて, 個々の言語療 法士が患者ごとに単語のセットを設定できるようにし てあることは，実際上きわめて有用であると考えられ る.

本装置については，これまで筆者の 1 人の病院で約 1 年間実際に試用して来た。 また少数ではあるが, 失 語症患者のうち, 意識障害, 手の失行, 視覚障害など のない 15 名に実施した結果, 約半数に使用可能であっ た. 本装置の使用に適合するか, しないかについては, いくつかの要因が関係していると考え, 現在使用症例 を増やして検討中である.

この訓練装置は, 上記使用可能な患者の約半数では, 自習可能であることが確認された。 また, カード操作 や音声の呈示の労力を省くという点で, 言語療法士の 負担を大幅に軽減することができる点でも有用である と考えられた。

なお, 今回の試作研究では, ある程度まとまった量 の絵カードと音声のデータが計算機上に用意されたの で, 今後, 種々の目的に応じて考案された訓練プログ ラムの作成に有用であると期待される.

今回の装置は卓上型の装置として製作された。しか し, 最近の小型可搬型計算機の性能向上は著しく, 今 回の試作プログラムの大部分は可搬型装置として実現 可能である.このような装置が実現されれば，患者の 病室内での自習や外来患者の自宅学習のための貸出が 可能となると考える. 現在, このような小型の装置の 開発も進めているところである.

\section{文献}

1）笹沼澄子, 正木信夫, 辰巳 格: コンピュータ技 術の導入による失語症訓練装置の現況と展望. 音 声言語医学, 30：255-262, 1989.

2) 丸山 勇, 河内十郎, 竹内愛子, 他：マイコンと ビデオを組み合わせた失語症自習訓練システムの 開発(1)ーハードウェアーを中心に一. 聴覚言語障 害, $14: 35-41,1985$.

3）中村美子, 田上美年子：マイクロコンピュータを 使った失語症のための言語訓練システム。聴能言 語学研究, $2: 214-215,1985$. 
4）小宮桂治, 菊池巧子, 小関公一, 他：マイクロコ ンピュータによる失語症補助訓練システムーシス テムの機能と書字訓練への応用を中心に, シリー ズ第 15 回臨床上の工夫 1 .言語聴覚療法, $9: 122$ $-129,1993$.

5）絵カード 98 , 絵カード 98 パート 2 , アルファシス テム, 大阪。

6）松田 崇, 他：機材情報第 5 回, 絵カードに類す
る訓練用機材. 言語聴覚療法, $8 ： 136-137,1992$.

7）笹沼澄子, 伊藤元信, 綿森淑子：失語症の言語治 療. 医学書院, 東京, 1978 .

別刷請求先： 1113 東京都文京区本郷 7-3-1 東京大学医学部音声言語医学研究施設 桐谷 滋 